\title{
SELECTED LETTERS TO SAMUEL WHITELEY BY SOUTH AFRICAN CLASSICISTS
}

\author{
$J$ Hilton (University of KwaZulu-Natal)
}

\begin{abstract}
This article publishes for the first time a selection of letters written to Mr Samuel Whiteley by William Smail, Theodore Haarhoff, Kenneth White, and Henry Tillyard, between 1923 and 1971. These letters were preserved among the papers and books donated by Whiteley to the Classics department at the University of KwaZuluNatal (then the University of Natal), in Durban. The letters are set in their historical context and analysed. They illuminate the history of Classics in mid-20th-century South Africa in a very personal way.
\end{abstract}

Keywords: Classics; South Africa; Letters; Whiteley.

\section{Introduction}

In addition to building up a substantial collection of artefacts in the Museum of Classical Archaeology over the years, ${ }^{1}$ past members of the Classics Department at the University of Natal, Durban, were fortunate enough to be able to establish an extremely useful teaching and research library, which was housed in the Department. The impetus for the establishment and growth of this departmental library, which has not been fully documented before, was undoubtedly Samuel Whiteley's bequest of his personal collection of books and journals (1109 volumes approximately). For this reason the library is known as the Whiteley Library (WL). Following his example, other members of the Durban department at the University of Natal also donated their collections, ${ }^{2}$ and when the decision was made in 2014 to transfer staff from the Pietermaritzburg Classics Department of the University of KwaZulu-Natal to Durban, their holdings were added. ${ }^{3}$

1 For the role of Professors B X De Wet and Anne Mackay in the development of the Museum, see Masters 2017, esp. pp. 310-314.

2 For example, Professor De Wet left his personal library consisting of some 866 volumes to the WL. On her death, Anne Gosling's brother, Michael, kindly agreed to donate her 629 books. Smaller collections such as books belonging to Giovanni Cipolla, Professor of Classics at the University of Durban-Westville, were given to the library by his son Marius, and a few of Ken Matier's books have also been added.

3 These volumes have never been catalogued. The hard work involved in transporting these books from Pietermaritzburg to Durban was undertaken voluntarily by postgraduate students at the time (Szerdi Nagy, Alan Ross, Francesco Lupi, Will Parker, Sonja Gammage, Lily Carrick-Tapeiner, and others). 
In addition to such donations, Professor De Wet was able, on his arrival in the Department in 1975, to take out subscriptions from the main library budget (the EG Malherbe library) for key journals, such as $J H S, J R S, C Q, C R, G \& R$, which were housed in the department. ${ }^{4}$ However, since the university would not provide the assistance of a librarian, the onus of keeping the Library going fell on the altruistic and willing labours of members of the Department. The card catalogue for the WL, for example, was compiled and maintained for many years by Anne Gosling and Aileen Bevis. Subsequently, I was able to construct an electronic catalogue using Endnote and to devise a simple issuing system for the Library. ${ }^{5}$ This electronic catalogue shows that there were approximately 8466 items in the collection (this does not included the many items transferred from Pietermaritzburg). The establishment of the WL, which is, to my knowledge, unparalleled in South African universities, was in part a consequence of the resistance by academics at the University of Natal to the decision of the library management to censor the holdings of the E G Malherbe Library that were deemed to be politically subversive by removing them from circulation. As a result, departmental collections grew up also in the offices of other disciplines, such as English, and so the WL was not unique, although it was larger than the others. ${ }^{6}$

Among the items in the WL were numerous letters, Latin prose compositions, original short stories, memoirs, postcards, photographs and other personal documents belonging to Samuel Whiteley. These had been left behind in the library after his death as part of his bequest to the department and were looked after for many years by Anne Gosling. The letters, dating from the time of World

$4 \quad$ Acta Classica and Akroterion were not included in these subscriptions, since staff were deemed to be subscribing to these journals via their CASA membership. Nevertheless, the WL also housed fairly complete runs of these journals also, as well as other journals, many of which arose from exchanges with Scholia, which was started at the University of Natal by Mrs A P Bevis, and further developed in 1992 by William Dominik. With the agreement of Professor Anne Mackay and other Durban staff members, the Loeb collection was transferred to the WL from the E G Malherbe Library. The WL also contained the full complement of volumes of Pauly-Wissowa's Realencyclopädie der Classischen Altertumswissenschaft, which was moved to it from the library of the University of Durban-Westville after the merger between this university and the University of Natal to form the new University of KwaZulu-Natal in the early 2000s.

5 The figures for the number of volumes donated by past staff members is taken from the electronic catalogue (books were given a call number to reflect the provenance of the donation, such as a prefixed $\mathrm{W}$ for Whiteley, BX for B X De Wet, and AG for Anne Gosling).

6 For this, see Buchanan 2008:171-173. However, this factor alone cannot explain the extraordinary growth of the WL, since the issue of censorship was raised in other universities during the 1960s. Instead it was mostly thanks to the philanthropic initiative of its founder and the spirit of cooperation among the members of the Department. 
War I, included blue aerogrammes written by South African, Sri Lankan, and British Classicists to Whiteley, who had built up a wide range of contacts over his career at Rhodes, St. John's College in Johannesburg, the Classics department in Colombo, and, of course, Queen's College, Oxford. ' In this article, selected letters from South African Classicists that reveal aspects of teaching and research in the discipline in the middle of the twentieth century appear in transcription. ${ }^{8}$ These letters are contextualised, as far as this is possible, and are accompanied by annotations.

\section{William Mitchell Smail}

One of the earliest letters in the collection is a formal letter from William Mitchell Smail to Whiteley on 20 June 1923. Smail, who appears in a group photograph of staff members at Rhodes University in $1922,{ }^{9}$ may have been the same man who is mentioned in the London Gazette in 1912 as a Lieutenant in the Royal Navy Volunteer Reserve force on the eve of World War I. ${ }^{10}$ Smail wrote to Whiteley concerning the latter's appointment to a lectureship in Classics at Rhodes University, which was then a constituent college of the University of South Africa. The letter shows that Smail was a resident, probably a warden, at the Graham House hall of residence at the university. The letter is of interest for its discussion of the curriculum that Whiteley could expect to teach: composition in the Classical languages evidently formed an important part of this, and the emphasis was clearly literary, featuring Plautus, Juvenal, and epic poetry (see further below). Student numbers do not appear to have been a problem since the classes were so large that they needed to be broken up into groups. The focus in acquiring books for the library appears to have been on 'standard works and editions'.

Perhaps the most remarkable aspect of the letter is that Smail adopts an apologetic tone, indicating that he felt that the students at Rhodes (which he describes as 'a very young institution' $)^{11}$ were ill-prepared for university study in Classics and that the 'open-air life' in South Africa was not conducive to

7 For brief accounts of Whiteley's life, see Matier 1986b, Matier 1986a.

8 It is my belief that publication of these letters is justified by the rise in interest in the history of Classics in South Africa following publications such as Parker 2017 and Lambert 2011. Every effort has been made to find the copyright holders of these letters and due acknowledgement will be made if they are located.

9 This photograph is mentioned in the catalogue of the Cory Library at Rhodes University, but to date the library staff have not been able to produce a scan of it despite numerous requests. Presumably it has been lost.

10 London Gazette 19 March 1912. The entry indicates that Smail was promoted from sublieutenant to lieutenant on 15 March 1912.

11 Rhodes was founded in 1904. 
'bookwork'. ${ }^{12}$ Consequently he asks Whiteley, who had just graduated from Queen's College, Oxford, to be 'patient and forebearing'. Nevertheless, he hopes that Whiteley will share his sense of 'the interest $\&$ value of pioneering work in a new country', and he mentions 'the range of our work in the department of Latin and Greek' with some pride. His letter regarding Whiteley's expected teaching responsibilities follows:

Graham House, Grahamstown, SA 20th June, 1923

\section{Dear Sir}

We heard last week that you had accepted appointment as our lecturer in Classics and I write to say how much pleasure it will give me to welcome you as a colleague. I trust that you will like the work here \& that you will speedily find yourself a home in Grahamstown. You have doubtless seen our College Calendar and noted the range of work in the department of Latin \& Greek: your work will be mainly in the Latin Department: the exact details can only be arranged after your arrival, as I should like to consult your own inclinations in the choice of books you have to lecture on. I told my brother to mention the Trinummus \& some of Juvenal as possibilities: I shall probably ask you to take entire charge of the Second Course \& perhaps of the postgraduate teachers' class. Then there is a 'Classical Culture' in which 'Epic' is this year a subject for special study - possibly that might suit you. The composition work of the first course will be mainly in your care. The class is so large that we have to work it into sections. Your lecture \& tutorial hours should not I think exceed 14 per week in the meantime. The college library is fairly well equipped with standard works $\&$ editions $\&$ are add [sic] as funds permit — we can usually manage to secure books specially wanted by any members of the department, if the cost is not excessive.

I think you will like the students here - they are eminently teachable $\&$ disciplinary difficulties hardly exist: The main trouble is that the majority are badly grounded at school \& are sent on to us before they are ready to profit by University courses, so that one must needs be patient and forebearing. The open-air life of this country tells against bookwork of any

12 According to Maylam 2017:113, Smail was much more scathing about the abilities of South African students in informal contexts. He doubted whether there were 'any prodigious geniuses among them', and labels them 'docile and stupid'. Maylam wrongly gives the initials of Smail as W A rather than W M. 
sort, $\&$ it is not surprising that the school standard of attainment compares unfavourably with home. We have not had any candidate for the Master's degree since the War, but there may be one or two coming forward ere long.

Our college is still a very young institution \& only part of our building scheme has materialised. I hope you will feel, as I do, the interest \& value of pioneering work in a new country.

I understand that you leave England on July 20: that will bring you to Algoa Bay on August 8 \& to Grahamstown on August 9. You will probably find it most convenient to go to the Carlton Hotel for a day or two till you can fix up suitable quarters. I shall try to meet your train on the morning of Aug. 9th \& see you then.

Yours very truly

William M Smail

Smail's own research was in the field of Roman education. In 1938 he published a short book consisting of selected passages on Roman education from Quintilian that is still widely available in South African and overseas libraries. By this time Smail, who left South Africa in 1931, was Rector of Perth Academy in Scotland. ${ }^{13}$

There is a second letter from Smail in the collection written almost thirty years later in 1952. At this time he was in Edinburgh, where he was working as a tutor at Edinburgh University and coaching private pupils in order 'to keep the wolf snarling at the gate'. It is evident that he was returning to Scotland for good after his years in South Africa, ${ }^{14}$ since he states that he had bought a bungalow in the suburb of Colinton 'some twenty minutes by bus from Edinburgh's centre, with a great view over farmlands to the Forth valley, the Ochils and the far-away peaks of Perthshire, only to be distinguished on clear days'. In this letter Smail mentions that his daughter and her family were returning to England after a long stay in Germany (presumably during World War II) and comments on how he impressive he found the reconstruction of Germany to be after the ravages of war. In the final paragraph he asks Whiteley to give his regards to 'K D, Liddell and Watson'. ${ }^{15}$

13 Smail 1938. The title page of this selection of passages from Quintilian in translation identifies Smail as 'Rector of Perth Academy'.

14 The name Smail is Scottish, which suggests that he was returning 'home' after his years abroad.

15 'K D' refers to K D White (see further below). Liddell and Watson were evidently also colleagues at Rhodes at this time. Liddell may refer to David Liddell, a fellow Scot and the Professor of Accountancy at Rhodes, according to the Rhodes Newsletter 9.2 (1969) 4. 
In this letter, Smail also indicates that both he and Whiteley were regular readers of The Critical Quarterly, since he recommends, without mentioning the title of the journal, the forthcoming article entitled 'The scalpel and the scales' by Graham Hough on literary criticism (1966). ${ }^{16}$ This is an indication of how strong the literary bias was in Classical Studies at this time.

Smail is also mentioned by K D White in a letter to Whiteley dated to 1971 as being blind, very deaf and suffering from 'some internal complaint'. ${ }^{17}$ According to this letter, Smail was in Toronto at this time, being nursed by White's youngest daughter, Catherine.

The on-going correspondence between Smail, K D White, and Whiteley, bears remarkable testimony to the long-standing friendships that these men established during their years teaching Classics in South Africa. Very strong bonds of affection appear to have been established between them that survived over some five decades in a number of different parts of the world.

\section{Theodore Johannes Haarhoff (1892-1971)}

The work of the South African Classicist, T J Haarhoff (1892-1971), has been discussed many times before. ${ }^{18}$ However, his five letters to Whiteley, the first of which is dated to 1946 (Haarhoff had got to know Whiteley during his time at St John's College, where they both taught ${ }^{19}$ ), reveal a more intimate side of his personality than is apparent in his academic writing, and accentuate his concern for social justice. Previous studies of Haarhoff's political views have emphasised that while he was certainly a liberal in South African terms, his liberalism should be seen within the context of relations between Afrikaners and English-speaking South Africans, rather than including the broader demands of Black nationalism. ${ }^{20}$ However, it is evident that so prominent a public intellectual as Haarhoff could not have ignored what was one of the most controversial political policies of the twentieth century. Two letters (dated to October and November 1960) survive that show that Haarhoff was far more aware of apartheid than he is usually supposed to

16 See also Hough 1966. Hough was also a regular contributor to The London Review of Books at the time.

1715 December 1971.

18 Lambert 2011:46-49; Whitaker 1997: esp. 6-11; Petrie 1958.

19 Letter to Whiteley, 23 December 1946. On 11 December 1947 Haarhoff writes to commend Whiteley for his 'Christian spirit', which he believed Whiteley 'understood better than any other man of my acquaintance'.

20 Parker 2010:228; Whitaker 1997:7-8; Petrie 1958:9. Haarhoff was a passionate advocate of the Afrikaans language ( $c f$. Haarhoff 1934), but he also spoke and wrote English fluently. For Haarhoff's promotion of the Afrikaans language, $c f$. Lambert 2011:45-47. 
have been. ${ }^{21}$ In the first (1960A) he mentions that he had visited the University of Fort Hare where he witnessed how 'personal friendship can break down theoretical race barriers' and that ' $[\mathrm{w}]$ ithin the framework of the Govt. (that we all thoroughly disapprove of) constructive work is being done through personal relationships'.

It is true that these startlingly direct statements follow a discussion of a recent issue of a recent South journal of adult education, Lantern, ${ }^{22}$ which had been devoted to the Classics. Here Haarhoff shows concern to keep 'a balance between Eng. \& Afr. articles'. However, in the second letter (1960B) the issue of the role of universities under apartheid is much more central. This letter appears to follow a letter or letters from K D White (see the reference to K D's belief that Haarhoff's visit to Fort Hare would make 'an interesting debate' in letter 1960B below), which have not survived, concerning Haarhoff's visit to Fort Hare. In it, Haarhoff makes it clear that his visit to the college had been undertaken on the invitation of three former principals. ${ }^{23}$ Haarhoff notes that his visit made it possible for him to meet 'non-white students who were not in the servant class' for the first time, as well as the 'white lecturers' responsible for teaching them. It is not clear, though, exactly how he was able to 'modify the abstract rules made by the Minister'.

What provoked Haarhoff to visit Fort Hare in November, 1960? It is likely that he undertook this high profile encounter because of what had happened at Sharpeville earlier in this year. On 21 March 1960, the South African police opened fire with live ammunition on a crowd advancing on the Sharpeville Police Station to protest against the pass laws, killing 69 protesters and wounding many others. The Sharpeville incident happened at a time when the treason trial against Nelson Mandela and his associates was going on, it led to the militarization of the ANC and the PAC, and aroused widespread international condemnation. ${ }^{24}$ In 1961 South Africa became a Republic and left the Commonwealth. ${ }^{25}$ Haarhoff was not alone in reacting with concern to this event. K D White almost certainly resigned

21 These letters of Haarhoff indicate that it is not entirely true that ' $[\mathrm{b}] \mathrm{y}$ its very nature, the study of Classics, especially in the early sixties before 1968 and the conscious politicization of knowledge, seemed remote from political and social realities', as argued by Lambert 2011:54, although it is true that the Classical Association of South Africa made no formal public statement regarding events at Sharpeville in 1960.

22 Lantern was a publication issued by the Adult Education Division of the Union Education Department from 1949-1995 (0023-8422). The series consisted of 44 volumes. For a retrospective account of the journal, see Van Zyl 1995.

23 Perhaps Dr A Kerr (1916-1948), Prof C P Dent (1949-1955), and Prof H R Burrows (1955-1959)?

See http://www.ufh.ac.za/About/Pages/PreviousViceChancellors.aspx.

24 On the consequences of Sharpeville see especially Lodge 2011:163-233; also Mandela 1994:224-226; Ross 1999:129-130; Welsh 2000:454.

25 Lambert 2011:54; Lodge 2011: esp. 163-233. 
his post at the University of Natal and left the country in 1962, along with many others, because of the political situation in South Africa (see the discussion below) ${ }^{26}$

(1960A)

S. Whiteley Esq. M.A.

"Harbour Lights"

Cato Rd.

Durban

NATAL

Almondbury, Stamford Rd, Rondebosch CT 23.10 .60

My dear Sam,

Many thanks for your letter. I am glad you are having the help of Hewitt ${ }^{27} \&$ I hope he will like Durban. Please give him my regards.

I asked the editor to send you a copy of the classical Lantern. ${ }^{28}$ He seems to have done it through K D.

What is your personal impression of the articles? I had to organise them according to institutions, holding a balance between Eng. \& Afr. articles. Then, at the last moment, I had to jump in \& do several articles myself because people cried off. My own feeling is that you would have done better than most of the performers. The illustrations were organised by the editor who is non-classical. Consequently some of the captions went wrong - e.g. the warrior of Agasias [illegible symbol] Aristophanes (I

26 Lodge 2011:171 notes that emigration from South Africa between the years 1959 (the Cato Manor riots in Durban) and 1962 exceeded immigration for the first time since World War II (however this was only temporary since the South African economy was booming in the late $1960 \mathrm{~s}$, which attracted a large number of immigrants); Lambert 2011:54; Henderson 2005:111, n. 14.

27 Hansell Hewitt, Whiteley's colleague at Rhodes University.

28 This was a special edition of Lantern Vol. 9.1 (September 1959), a journal published by the Department of Adult Education, under the general editorship of Haarhoff (Haarhoff 1959). 
cannot agree with Maiuri's suggestion that it might be Aristophanes \& prefer the old idea that it might resemble Seneca). ${ }^{29}$

I had a most interesting time at Fort Hare \& saw again how personal friendship can break down theoretical race barriers. Within the framework of the Govt. (that we all thoroughly disapprove of) constructive work is being done through personal relationships.

Every good wish to you both

Yrs cordially

Theo Haarhoff

(1960B)

Almondbury, Stamford Rd, Rondebosch

(Letterhead crossed out: 'UNIVERSITY OF THE WITWATERSRAND, JOHANNESBURG, Telephone 44-3781, Milner Park, Johannesburg')

$7 / 11 / 60$

My dear Sam,

It was very pleasing to have your letter. K D said that my going to Fort Hare would make an interesting debate, but I was not concerned with abstract debates. I went with the encouragement of three former Principals of Fort

29 On p. 78 of the Lantern volume the caption for 'The gladiator by Agasias of Ephesus' and 'An Athenian warrior scultped on a votive stele' are in the wrong order. The socalled gladiator by Agasias of Ephesus is also known as the 'Borghese Gladiator' because it once belonged to the collection housed in the Villa Borghese. The tree trunk supporting the figure bears the signature of Agasias of Ephesus, son of Dositheus, and it is probably a copy of an original by Lysippos (fourth century BC). The Maiuri referred to here was no doubt Amedeo Maiuri, the famous archaeologist associated primarily with the excavation of Pompeii and Herculaneum, since his book on Pompeian wall painting is referred to on p. 74 ('Pragtig word hierdie kleure weergegee in Maiuri se boek oor die Romeinse skilderkuns' = Maiuri 1960). See also, for example, Maiuri 1951; Maiuri 1956. Ever since the time of Von Thiersch 1829, many theories about the identity of the warrior have been put forward. 
Hare. I found practical work to do. First, I could help the students (the Classics people sent me 15/- worth of book tokens - most touching!), second, I could help to modify the abstract rules made by the Minister, third, I could gain experience of non-white students, fourth, I could witness the experience of white lecturers, who, for the first time, met non-white students who were not in the servant class.

You will be coping with exams \& you have my sympathy. I too will be ploughing through the 'deserta locorum'!

Have you seen Jack Lindsay's book on the Pompeian graffiti - 'The writing on the wall'? ${ }^{30}$ A lively account based on real knowledge but leaving out the significance of the 'Villa dei Misteri'.

There is also a book by Von Vacano on the Etruscans, translated from the German (Arnold) ${ }^{31}$ which seems interesting.

Every good wish to you both,

Theo Haarhoff

These letters also show the shared interest of Haarhoff and Whiteley in the Classics, and, in this case, in ancient art and archaeology, covering broad periods: the Etruscans, Pompeii, and Roman copies of Hellenistic sculpture.

The issue of Lantern that Haarhoff mentions in his letter (1960A) illustrates this range of interest particularly well. As Haarhoff notes in his letter, he was responsible for much of this volume (eight out of the nineteen chapters), including contributions on 'Die geografiese agtergrond' (pp. 4-9), 'The framework of Greek and Roman History' (pp. 10-15), 'Die lewe van die gewone mens' (pp. 28-33), 'Literature' (together with Maurice Pope, pp. 46-53), 'Religion' (pp. 54-55), 'Should modern science return to the study of antiquity?' (pp. 61-64), 'Opvoeding en kuns' (pp. 72-77), and 'The continuity of the classical tradition' (pp. 106-107). This special issue was clearly intended to popularise Classics, but it also reflects the research interests that were current at the time: Maurice Pope and Simon Davis, for example, on Linear A and Linear B respectively (pp. 20-24), ${ }^{32}$ Simon Davis on archaeology and papyrology (pp. 24-27), ${ }^{33} \mathrm{~K}$ D White on 'Agriculture, commerce, and industry' (pp. 34-41), ${ }^{34}$ and André Hugo on 'Erasmus van Rotterdam' (pp. 99-

\author{
Lindsay 1960. \\ Von Vacano 1960. \\ See, for example, Pope 1999; Davis 1968. \\ Davis 1951. \\ See the publications of K D White mentioned below.
}


105). ${ }^{35}$ Some of the contributions gave the publication a particularly South African feel with chapters by H L Gonin on 'Die Romeinse reg en sy rol' (pp. 28-33), 'Rigtings in die wysbegeerte' (P V Pistorius and F Smuts, pp. 56-60), 'Die manuskripte van die Bybel' (P V Pistorius, pp. 78-83), 'Die latynse literatuur van die Christene' (W Lubbe, pp. 84-95), and 'Augustinus' (W N Coetzee, pp. 96-98). One of the longest contributions was by Rita Elferink on 'Die boukuns van die Grieke en die Romeine' (pp. 65-71). The chapters are lavishly illustrated with photographs acquired during visits to Greece and Rome sponsored by the Greek and Italian embassies to South Africa.

\section{Kenneth Douglas (K D) White (1908-1998)}

K D White was a Classics graduate of Peterhouse College, Cambridge, but he became a Fellow of St John's, Cambridge, in 1960-1961, when he returned to the UK after twenty years teaching in South Africa. ${ }^{36}$ In South Africa he had been appointed to the post of Professor of Classics at Rhodes in $1938 .{ }^{37}$ In 1945 he was head of the Classics department at Rhodes and responsible for the appointment of Whiteley to a temporary post in Classics after the latter's time teaching at St John's College, Johannesburg (1942-1945). ${ }^{38}$ In another letter (1946) he tells Whiteley how pleased he was that he had accepted the appointment 'to my staff'. ${ }^{39}$ Staffing questions continued to feature in his correspondence in 1948, at which time he was also acting as Warden of Drostdy Hall (a residence for Rhodes students). ${ }^{40}$ In 1958

35 For Hugo's interest in the later influence of the Classics, see Battles and Hugo 1969.

36 See John Crook's cursory obituary for K D White, in the St John's College, Cambridge, magazine, The Eagle (Crook 1999) and also Guite 1998; Whitaker 2004. According to Maylam 2017:113, K D White served as a city councillor in Grahamstown for ten years.

37 According to John Jackson, K D White was appointed as Professor of Classics at Rhodes in 1938 at the age of 29. Crook's obituary mentions '20 years of Chairs in South Africa' and that White returned to Cambridge in 1960. No inaugural lecture by White survives, to my knowledge, and none is referred to by Lambert 2011. Henderson 2004:92 gives White the title of Professor, when noting his appointment as Vice-Chair of CASA in 1956, for the period 1957-1958. As Vice-Chair, White had undertaken to liaise with museums in Italy and sent a letter of support to the Classical Association of Rhodesia in Latin (Henderson 2005:93, 97).

38 K D White, letter to Whiteley 20 November 1945 . Whiteley had taught at Rhodes before (1928-1935), after which he was appointed to the Chair of Classics, at Colombo, Sri Lanka (1935-1942). On his second appointment, Whiteley stayed at Rhodes until 1957, when he moved to Durban.

39 K D White, letter to Whiteley 15 January 1946. The chairs of Greek and Latin had been combined at Rhodes in 1945.

${ }^{40}$ K D White, letter to Whiteley, 28 October 1948, concerning H J W Tillyard. 
K D White moved to the University of Natal, where he was appointed as Professor of Classics in Pietermaritzburg until 1962, when he moved to Nigeria. ${ }^{41}$

According to John Crook (and his testimony must have been based at least on a personal conversation) White left Rhodes 'in flight from the culture of apartheid'. ${ }^{42}$ White's departure from South Africa in mid-career at this time was in all probability ultimately connected with events at Sharpeville on 21 March 1960, as discussed above, although it evidently took two years for him to extricate himself from his position as Professor of Classics at the University of Natal. If so, and it is difficult to see how it was not, his action was in keeping with that of Haarhoff, who visited the Fort Hare Native College in 1960. In fact, Haarhoff mentions that White had suggested that 'going to Fort Hare would make an interesting debate' (Haarhoff 1960B, above), which indicates that White had been corresponding with Haarhoff about political events in South Africa and that he felt strongly enough about the matter to want to raise it with other Classicists.

While in South Africa White had been active in the promotion of Classics and gave a radio lecture on the SABC entitled Our Classical Tradition (1958). ${ }^{43}$ This was not an entirely unusual activity, since Whiteley had given a weekly talk for six weeks on the SABC aimed at school-children on world affairs in $1940,{ }^{44}$ and in 1957 a series of six lectures in Afrikaans entitled Ons Klassieke Erfenis (= 'Our Classical Tradition') had been broadcast by the SABC-SAUK. ${ }^{45}$ Nevertheless, a recent analysis of White's SABC broadcast has insinuated that in this radio talk White took sides with White South Africans 'in opposition to the "dark forces" of black South Africa' (p. 169). ${ }^{46}$ Not only is there no justification for this assertion in the text of White's broadcast - the quotation is concocted from two separate phrases some twenty-six pages apart in the original — but it also completely misjudges White's political views, which, as noted above, were so strongly opposed to the policy of apartheid that he resigned his post at the University of

41 White's translation of Gysbert Hemmy's De promontorio bonae spei in 1959 describes him as 'Professor of Classics, University of Natal'. See also Maylam 2017:112, who states that K D White resigned from Rhodes University in 1958.

42 Crook 1999.

43 White 1958.

44 According to Ken Matier's unpublished account of Whiteley's career.

45 The six lectures were: 1. Rome en sy klassieke reste (C G S de Villiers), 2. Griekse en Romeinse argitektuur (Brian Sandrock), 3. Die spore van Latyn en Grieks in die Afrikaanse woordeskat (B Kok), 4. Die letterkundige nalatenskap van die Grieke (J P J van Rensburg), 5. Die letterkundige nalatenskap van die Romeine (T J Haarhoff), 6. Die nalatenskap van die antieke wêreld op die gebied van die regswetenskap (K Schwietering).

46 Richardson 2013:161-169. See Stray 2014 and the accompanying blog, supported by Hilton 2014: esp. p. 271. 
Natal in 1962 and took up an appointment at the University of Ibadan in Nigeria for three years (1962-1965) ${ }^{47}$ White also took an interest in the early history of the Cape and translated Gysbert Hemmy's De promontorio bonae spei (1959). ${ }^{48}$

The following letter shows that it took White some years to re-establish himself in a permanent position at Reading (1971) after his years in Nigeria, and may explain the rather manic emphasis he places on his own publications. ${ }^{49}$

As from: Massey College

4 Devonshire Place

Toronto 5

Canada

15th December 1971

My dear Sam,

I hope this will arrive in time to carry its message of Christmas goodwill and a prosperous New Year. In case you are behindhand with news from this end, I have been at the above address since early in August working (very gently and at decent intervals) in the guise of a Visiting Professor at University College, Toronto. The place is very antique (University College, I mean) with a fantastic new-Gothic facade said to have been designed in 1851 or so to cover all aspects of 'The Gothick' that might be required by a student of the history of this form. The department is very large, with some 40 instructors of all grades covering a number of different institutions all operating under the general umbrella of the U. of Toronto. Present staff whose names may ring a bell include Kenneth Quinn (Catullus \& Virgil), Mary White (Thucydides etc.), Graham Sumner (formerly Rhodes \& Canterbury, N Z - now Chairman of the Department (Roman Republican history), \& John Rist (Chairman of the Graduate Dept., whose book (a general survey) on Epicurus is about to come out. There are some $30 \mathrm{Ph} . \mathrm{D}$. students around, all told. I have only 1 undergraduate course to teach (Roman Republic 44?-31 BC) and have two long terms in which to teach it, so plent[y] of time to work to some depth. My students seem to come from all over the place (two from Music and 1 from Medicine!) - result of the 'elective' system recently introduced from over the border. Whatever the demerits of the system, the effect on the individual instructor is that you

47 Lambert 2014:4. According to Crook 1999, K D White also returned to Nigeria to teach at Jos after his time at Reading.

48 Hemmy 1959.

49 It is noteworthy that most of White's significant publications date from after he left Africa. 
only have in the class who want to read R.H. as against those who are required to take it. My first essays are just in, and some of them look uncommonly good. The class atmosphere is very friendly and very informal - they interrupt me with questions ad lib. (there are only 20 of them) and I'm being quite successful with a once-a-fortnight session of papers given by individual members. There will be no formal examination paper instead the work will be assessed on their class papers \& one short $\left(2 \frac{1}{2} 000\right.$ words) and 1 long (5 000 word) essay.

Although U. of $T$. is vast $(30,000$ students) the collegiate pattern means that one is not all the time overwhelmed by the fuss of size. The library is impressive with over 3 million vols. \& particularly strong in journals. We have had some pretty good people in the past, including Charles Norris Cochrane, Fritz Heichelheim and we now have both the Alföldis (husband is theoretically at Princeton but often here and wife is in archaeology here). ${ }^{50}$ The subsidiary undergrad. library facilities are good with multiple copies of standard works available. All the libraries are open till 10 p.m. every day including Sunday!!

I have a graduate seminar next term which should be interesting, but I'm not really very [illegible]! I am the only economic historian around the place and there are almost too many literary chaps around. In this sense the Dept. is ill-balanced. If I were staying here I would try to build up a good graduate programme in anc. history. But I'm back in the U.K. in April - to take up a Research Fellowship at Beckton ${ }^{51}$ for the Trinity term. In the meantime I am trying to write a (in collaboration with John Landels of the University of Reading) a book on Gk. \& Roman technology. ${ }^{52}$ I'm also finishing off a companion volume for C.U.P. to the implements book which will be called Farm Equipment and will include all the various pots, bags, sacks, etc..$^{33}$ The text is virtually complete, but I have still to do work on the illustrations. Finally, I'm going to write a Pelican with the title Country Life in Classical Times ${ }^{54}$ which will consist of passages in translation on all aspects of life in the country - hunting as well as farming. I shall begin with the agric. scenes from the Shield in Iliad XVIII, and end up with the description of treading the grapes from the Geoponika. Any favourite

50 This probably refers to Andreas Alföldi and Maria Alföldi.

51 The word is difficult to make out in White's handwriting, but Beckton College in the University of London may be meant.

52 This later appeared as White 1984. For Landels, see Landels 2000, Landels 1999.

53 White 1975.

54 White 1977 
passages you'd like included will be gratefully [illegible word received?]! At the moment of writing [illegible] has arrived for 4 weeks holiday from London, and the four of us (James and Carol) are spending a few days in the beautiful Muskoka lakes. We arrived in a snow storm, but unfortunately the temperature has been rising all day and it has [illegible word] all turned to a rather treacherous slush! Our younger daughter, Catherine, has just finished her degree at Edinburgh - she graduated B.Sc. with distinction and is now on the last leg of the course which will give her in addition a full nursing qualificat[ion]. She has been nursing Professor William Smail, who alas is now blind and very deaf. Isobel went to see him $\&$ he remembered you and wished to be remembered to you. He is more or less permanently hospitalised, for he has some internal complaint as well as the above disabilities. I had a long letter in the other day from Ken Matier, now on sabbatical in Oxford. He looks forward to seeing me then in the summer, before returning to Rhodes. I had a splendid but exhausting two days assignment at the University of Pennsylvania at Philadelphia, addressing the graduate dept. on the recent work on Italian land settlement problems. I've had research grants for this from Leverhulme, and have still quite a lot of fieldwork to do, trying to identify Roman farm settlements I hope eventually to write something like an agrarian history of Roman Italy, which will put the Gracchan legislation and other political developments into a full agrarian setting. ${ }^{55}[\ldots]$ by day quite a bit of reviewing too. And finally Reading has given me a personal chair! The Reading people have [...] in $1965 .{ }^{56}$

All good wishes to both of you, Elizabeth and the family from us all.

Yrs. ever, K.D.

\section{Henry Julius Wetenhall Tillyard (1881-1968)}

Some twenty-two letters by the Byzantine musicologist Henry Tillyard survive among the Whiteley papers. Tillyard took his degree at Cambridge, where he won the Prince Consort Prize in 1907 for a study of Agathocles, the tyrant of Syracuse. ${ }^{57}$ During World War I he was interned in the Ruhleben internment camp near Berlin. ${ }^{58}$ Some letters and postcards from this time, written in German and English,

55 To my knowledge, this book was never published.

56 The last sentence of this letter is illegible but was probably a reference to the fact that White had taught at Reading in 1965 as a lecturer.

57 Tillyard 1908.

58 For Ruhleben camp, see Powell \& Gribble 1919. 
are preserved in the archives at the University of Leeds. After the war, he was appointed to the chair of Greek at Cardiff University (1926-1946). ${ }^{59}$ After leaving Cardiff, Tillyard was appointed at Rhodes on a 'year-to-year basis' ${ }^{60}$ However, in 1948 White felt that he needed to appoint someone 'fairly fresh from Oxf. or Cambr.'. In any case, although Tillyard wanted to stay on in South Africa, he was 'outvoted 3-1' by his family ${ }^{61}$ and he returned to the UK on the 'Cape Town Castle' on 4 December 1948. His letters to Whiteley, to whom he expresses thanks for his friendly hospitality in Grahamstown, ${ }^{62}$ date from after this time (19481967).

Tillyard's publications are impressive. In addition to his researches on Byzantine chant, ${ }^{63}$ he published articles in the field of Greek archaeology in his early years. ${ }^{64} \mathrm{He}$ also translated from Latin the plays of Roswitha, a $10^{\text {th }}$-century nun from Saxony, and wrote several paedagogical articles on Latin and the study of Prudentius. ${ }^{65}$ Besides these works, he also found time to compose two volumes of poetry, ${ }^{66}$ a Russian poetry reader, ${ }^{67}$ and an essay on the modern Greek language question. ${ }^{68}$ However, it is his comments on South Africa that make him a figure of interest for the history of Classics in South Africa. For example, in a letter dated 4 December 1948 he writes:

We have just heard by wireless the calamitous news of Hofmeyr's death. It is a blow. S. Africa has no-one to take his place; and his poor old mother is not likely to get over it. I had just sent my greetings to them from Cape Tn. with hopes for his recovery, now all too late.

Tillyard's comments on South Africa in 1952 show how uncertain the political situation was at that time. In the following letter, which is notable for the breadth of Tillyard's interest in Classics (Horace, Philodemus, Caesar, Ovid) and in the history of ideas (Russell), Tillyard observes that he found it necessary to reassure

59 See the obituary for Tillyard written by Velimirović 1968 . This obituary neglects to make any mention at all of Tillyard's connection with South Africa.

60 Letter of K D White to Whiteley, 26 January 1948.

${ }_{61}$ Letter to Whiteley, 12 February 1950.

62 Letter to Whiteley, 12 February 1950. Tillyard also visited the Whiteleys in Durban.

63 See the bibliography of these works in Wellesz et al. 1966:1.xv-xvi.

${ }^{64}$ See, for example, Tillyard 1904-1905, Tillyard 1905-1906.

${ }_{65}$ Tillyard 1947, Tillyard 1958; Tillyard 1962.

66 One of these was published as Tillyard 1964. In a letter to Whiteley dated 8 October 1950, Tillyard thanks Whiteley for his review of his poetry volume and states: 'You saw the main point, viz. that they are meant for fun, not satire, and I am most grateful for your praise and understanding'.

67 Semeonoff \& Tillyard 1917.

68 Tillyard 1920. 
his nervous friends, who were contemplating repatriating their investments in the country.

15 Brooklands Aven, Cambridge

$23^{\text {rd }}$ May' 52

\section{Dear Whiteley}

Many thanks for your letter. It is true that a technical training leds to higher pay than a liberal education: but still a good degree in Maths. can always command a tolerable salary: and I think that mathematicians are a happy crew, because the stormy world outside does not touch their placid contemplations - unless they reach the end of all things, where Bertrand Russell seems to have found disappointment. At the Rectory in the country, where my sister has been staying one daughter was incurably 'horsy' and made the despair of her parents. Then they heard of a 'beast-leech' who had a hospital for horses near here; and he wanted someone to take the patients out for exercise. So the young woman was taken on as stable-maid and is perfectly happy. Only of course one does not know how long such things last.

I send you a small book of verses by a man who was a master at the Leys school, whom I know slightly. It was in paper covers, but I have bound it myself, after a fashion. A good deal of the verse is a commentary on Horace. This unkind opinion - that Horace had 'nothing to say' and only made experiments in Greek metres and adapted Philodemus in order to flatter the Emperor, was or is fashionable at Oxford. But I was glad to find that a learned German schoolmaster, whom I met last year, is very much against it. So it is also with poor Caesar - after Mommsen, they made him a mere adventurer; and Mussolini had the impudence to claim him as his pattern; but now I find that Mr. Felix Grendon ${ }^{69}$ turns him into a glorified Ramsay Macdonald and Stafford Cripps rolled into one, ${ }^{70}$ after whitewashing him from head to foot.

69 Probably a reference to Grendon 1941.

70 Ramsay Macdonald (1866-1937) and Stafford Cripps (1889-1952) were both British Labour politicians in the first half of the twentieth century. 
We are all well; and my daughter-in-law me fecit avum (as Ovid puts it). ${ }^{71}$ We hope to see the grandson in Wales in Aug. Constance is well and busy, giving cello lessons and trying for her driver's licence, to which a pretty face is not so safe a way as it was in S. Afr. Still she has plenty of nerve and ought to pull it off next time. We expect a nephew from Germany to stay next month. Weather fine and warm - an early summer. My own book, though all printed, is still not out. ${ }^{72}$ I hope you will get the 'rise' that Prof. Wh. is seeking. I try to soothe my friends, when they grow uneasy about S. Afr. and think of touching their investments. Surely some modus vivendi will be found!

My wife and Constance join with me in best to you all,

Yours ever

H J W Tillyard

Tillyard retained his interest in South Africa and Rhodesia, which had first begun in $1919,{ }^{73}$ for many years. In 1954 he comments: 'Davis was a temporary lecturer at Wits. In 35/6 I looked on him as a man of promise \& advised Haarhoff to keep him. So now he has climbed to the top. ${ }^{74}$ I should be glad to see Petrie; but he must have a whole clan in Scotland wanting to put him up'. In the same letter he tells Whiteley that the British Academy had granted him funds to visit Malta to inspect an MS 'forgotten by other students of Byz. Music'. He also informs him that he had published two articles recently about which he states that they are 'worthless indeed; but my colleague Prof Wellesz had begged me to defend him against an unkind Swiss reviewer'. ${ }^{75} \mathrm{He}$ mentions also his connection with German Classicists: 'I had some amusement in Germany reading Horace \& Martial with a retired headmaster: only he had said: "My voice is too weak: will you read the Latin \& translate into German?" A stiffish viva! Martial was fairly easy but Horace - ! Yet I was glad for he showed a real \& deep love of the classics'.

${ }^{71}$ Ovid. Trist. 4.10.75-76: filia me mea bis prima fecunda iuventa, / sed non ex uno coniuge, fecit avum ('my daughter in her early youth, twice fertile but not by one husband, made me a grandfather').

72 It is unclear whether this refers to Ayoutanti et al. 1952 or Tillyard 1952b, possibly the latter as this was authored by Tillyard himself as opposed to the jointly authored Hymns of the Hirmologium.

73 Letter to Whiteley 21 February 1961. Sanctions on Rhodesia are mentioned in a letter to Whiteley dated June 1967.

74 Letter to Whiteley 6 June (Whitsunday) 1954. Davis was appointed Professor of Classics at the University of Natal, Pietermaritzburg in 1953. See Davis 1953.

75 Tillyard 1952a; Tillyard 1953. 
In 1961 Tillyard states that he hopes to visit his 'gifted friend', the South African composer Hubert du Plessis, ${ }^{76}$ and that he met up for tea with K D White, who had just 'negotiated some research grant ... to his utmost satisfaction', after bumping into him at the University Library in Cambridge. ${ }^{77}$ In this year also, he embarked on research on the Roman Empire, Cicero, and Caesar, as a letter dated to 28 July 1961 indicates:

I have cleared up the istum latronem passage in Pliny. ${ }^{78}$ It was Stuart Jones in his book on the Roman Empire (Story of the Nations series) ${ }^{79}$ who seems to have brought in the Emp. Domitian without any authority (see note enclosed). I have finished my sketch of Cicero's life during the Civil War; and now have started making notes on [Caesar] Bellum Africanum, which would be a good text for boys in their $3^{\text {rd }}$ year of Latin - easier than de Bello Gallico \& quite good Latin. I hardly think that any publisher would smile at these senilia.

The Tillyards were friends with many South African Classicists, including the Haarhoffs. Tillyard notes that he and his wife had tea with 'Mrs Haarhoff' but that her son had a cold and could not take Mina ${ }^{80}$ for a walk up Table Mountain, 'which she did in 1921'.

Tillyard maintained his interest in Classics in his last years. On 18 May 1966 he writes:

Cornford's little book ${ }^{81}$ amused my brother, who, if anyone, ought to have understood the mind of Cambridge dons. I found it rather flat, never having been one myself. (It was my mother's ambition for me; but as it turned out, luckily for me, it came to nothing.) C. [sic] longer book Thucydides

76 May 2011. In 1961 Tillyard gave a lecture on Byzantine music to Du Plessis's class (letter to Whiteley 5 October 1961). In the same letter Tillyard expresses surprise at Du Plessis's support for Duresco after his return to Vienna. See also a letter to Whiteley dated November 1953 which mentions that Du Plessis was 'hard at work at the Royal Acad. of Music \& is writing a symphony'. Du Plessis's tour of Europe is referred to in a letter to Whiteley dated 18 May 1966.

77 Tillyard also remembers K D White in a letter to Whiteley dated 26 June 1967.

78 Plin. Ep. 1.12.8. The actual passage is: 'cur', inquit, 'me putas hos tantos dolores tam diu sustinere? ut scilicet isti latroni vel uno die supersim'. 'Why', he said, 'do you think that I bear such great pain for so long? Obviously, so that I may survive that bandit even by one day'. Tillyard's solution to this passage has not survived.

79 Jones 1908:131-148, esp. 145-146 (for the isti latroni passage).

80 Mina was Tillyard's German-born wife, see letter to Whiteley November 1965, and 26 June 1967.

${ }^{81}$ Probably Cornford 1964 is meant. 
Mythhistoricus $^{82}$ was a pallid reflection of Verrall and J. G. Fraser, though one might find a few hints in it. (Prof. Bury disagreed strongly.)'

Later in the same letter he says 'I thought of writing on Boethius for Prof Smuts' paper, but decided that it would only tire my eyes, while you and he, perhaps, would be the only readers. Still I am glad to have read most of the De Consol. in Latin. ${ }^{83}$ On 31 August 1967, Tillyard writes on the occasion of Whiteley's retirement: 'I have packed up what I have of Lucian and also Arrian. With more time and better eyes one might find good enjoyment in Lucian, in spite of his wrong optatives; but Arrian, whom Wilamowitz-M $\mathrm{M}^{\mathrm{f}}$ had to read at boarding school, is correct but dull' and later on 4 November 1967: 'There is always something to say about Horace!'.

\section{Conclusion}

This article has presented new evidence for teaching and research in Classics as practised by four Classicists in the early to mid twentieth century. It is striking that in nearly all cases, the major publications of these men appeared after they had left the country. This can be attributed no doubt to the very high teaching load that they were responsible for in South Africa. Nevertheless the letters also reveal much about the range of interests of these men, and their astonishing love of and dedication to discovering more knowledge about the ancient world of the Greeks and Romans. At the centre of this circle was Whiteley, who formed bonds with all of them, and who cultivated friendships with them all for many decades (from the 1920 s to the 1960s). It is remarkable that in most cases, these scholars had close connections with Germany, despite the fact that two world wars involving Germany and the UK broke out over this period. These bonds were maintained by the mutual exchange of letters and books, which perpetuated the tradition of litterae humaniores in a context that was completely new. The letters reproduced and contextualised here show that Classicists in South Africa were indeed sensitive to the political and economic situation in the country, and while most of them came from and eventually returned to the United Kingdom (Haarhoff being the exception), they maintained a concern for the future of the land that was sustained for many years after they had left.

${ }^{82}$ Cornford 1965. Both of these books by Cornford were reissues.

83 'Prof. Smuts' paper' presumably refers to Akroterion. I am not aware of any publication by Tillyard in Akroterion or Acta Classica. The letter also refers to "Miss Baumbach, now happily settled at the Cape, but out of touch with "Rhodes". She is also remembered in Tillyard's letter to Whiteley on 26 June 1967, and 4 November 1967 (as preferring Cape Town to Pretoria). 
SELECTED LETTERS TO SAMUEL WHITELEY

171

3 Reform Attune, Mare, The.

16. $\pi .48$

dem whitely,

If you know Mallee, you art ll feel

some simpers at aug living in dec an

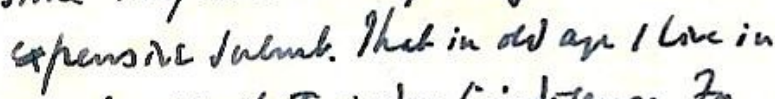
considarobes slate is due ('indigence. In when I was honking for a corm a friend suppurated any occupying the house of sens friends of has during their absence abroad. 1 moved in m Sang 19 .

Resuyg s that the dali of the omens'

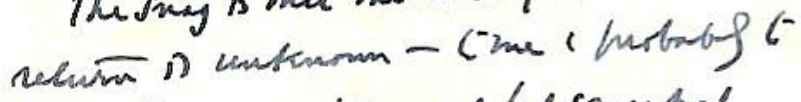

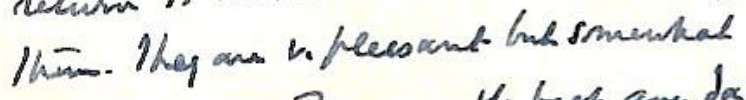
curation prese The man th back any do y.

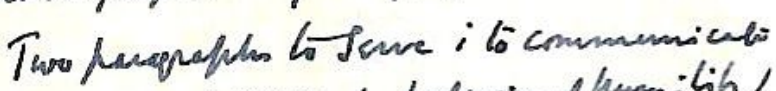

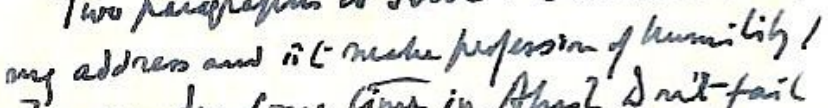

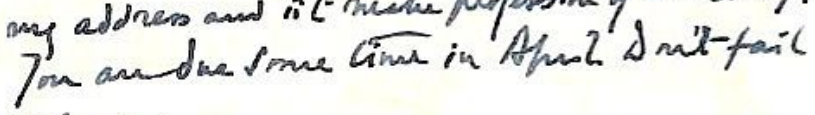

is ten me.

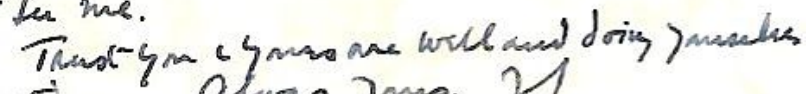

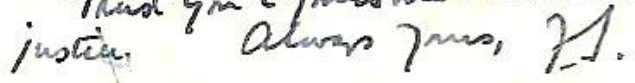

Letter of T J Haarhoff to Whiteley, 16 March 1948. 


\section{BIBLIOGRAPHY}

Ayoutanti, A, Stöhr, M, Høeg, C, Raasted, J, Tillyard, H J W \& Monē Ivērōn (Athos Greece) 1952. The hymns of the Hirmologium. Union académique internationale monumenta musicae byzantinae transcripta. Copenhagen: Munksgaard.

Battles, F L \& Hugo, A M 1969. Calvin's commentary on Seneca's De Clementia. Leiden: E J Brill.

Buchanan, N 2008. A history of the University of Natal libraries, 1910 - 2003. $\mathrm{PhD}$, UKZN Library: University of KwaZulu-Natal, Durban.

Cornford, F M $1964^{6}$ [1908]. Microcosmographia academica: Being a guide for the young academic politician. London: Bowes \& Bowes.

1965 [1907]. Thucydides mythistoricus. London: Routledge \& Kegan Paul.

Crook, J 1999. K D White. The Eagle 307: no pages.

Davis, S 1951. Race-relations in Ancient Egypt: Greek, Egyptian, Hebrew, Roman. London: Methuen.

— 1953. The study of the Classics: An inaugural address delivered at Pietermaritzburg on $1^{\text {st }}$ October, 1953. Pietermaritzburg: University of Natal Press.

1968. The Decipherment of Linear A. Studi micenei ed Egeo-anatolici, 90110. Roma: Edizioni dell' Ateneo.

Grendon, F 1941. No other Caesar. London: J Lane.

Guite, H F 1998. Obituary: Professor K D White. The Independent July 4:7.

Haarhoff, T J 1934. The Achievement of Afrikaans. Johannesburg: Central News Agency.

Haarhoff, T J (ed.) 1959. Our Classical heritage: A special issue of Lantern Vol. 9.1. Pretoria: Departments of Arts and Science.

Hemmy, G (trans. White, K D) 1959. De promontorio bonae spei $=$ The Cape of Good Hope: A Latin oration delivered in the Hamburg Academy, 10 April 1767, translated and edited by $K D$ White with additional notes by $G S$ Nienaber and D H Varley. Cape Town: South African Public Library.

Henderson, W J 2004. The Classical Association of South Africa April 1956 January 1961. Akroterion 49:89-109.

_ 2005. The Classical Association of South Africa February 1961 - July 1966. Akroterion 50:109-123.

Hilton, J L 2014. Review of Richardson, E 2013. Classical Victorians: Scholars, scoundrels and generals in pursuit of Antiquity. Classics after Antiquity. Cambridge. Acta Classica 57:267-272.

Hough, G 1966. An essay on criticism. New York: Norton. 
Jones, H S 1908. The Roman Empire, BC 29 - AD 476. Story of the nations. London: Fisher \& Unwin.

Lambert, M 2011. The Classics and South African identities. London: Duckworth. 2014. On rainbows and butterflies: The classics, the humanities and Africa. Acta Classica 57:1-15.

Landels, J G 1999. Music in ancient Greece and Rome. London: Routledge. $2000^{2}$ [1978]. Engineering in the ancient world. London: Constable.

Lindsay, J 1960. The writing on the wall: An account of the last days of Pompeii. London: The Book Service.

Lodge, T 2011. Sharpeville: An apartheid massacre and its consequences. Oxford: Oxford University Press.

Maiuri, A 1951. Pompeii. Novara: Agostini.

— (trans. Priestley, V) $1956^{8}$. Pompeii: The new excavations, the 'Villa de Misteri', the Antiquarium. Roma: Instituto poligrafico dello stato.

1960. Pompeian wall paintings. Orbis pictus (Bern, Switzerland). Berne: Hallwag.

Mandela, N 1994. Long walk to freedom. Randburg: Macdonald Purnell.

Masters, S 2017. Museum space and displacement: Collecting Classical antiquities in South Africa. In Parker, G (ed.) South Africa, Greece, Rome: Classical Confrontations, 283-315. Cambridge: Cambridge University Press.

Matier, K O 1986a. In memoriam: Sim Whiteley (4.12.1896-14.6.1986). Akroterion 31.2-3:35-36.

1986b. Mr S Whiteley: A tribute. Acta Classica 29:1-2.

May, J 2011. Obituary — Hubert du Plessis. Journal of the Musical Arts in Africa 8.1:115-116.

Maylam, P 2017. Rhodes University 1904-2016: An intellectual, political and cultural history. Grahamstown: Institute of Social and Economic Research, Rhodes University.

Parker, G 2010. Heraclitus on the highveld: The universalism (ancient and modern) of T J Haarhoff. In Vasunia, P \& Stephens, S A (eds.) Classics and national cultures, 217-234. Oxford: Oxford University Press.

Parker, G R (ed.) 2017. South Africa, Greece and Rome: Classical confrontations. Cambridge: Cambridge University Press.

Petrie, A 1958. Professor T J Haarhoff - An appreciation. Acta Classica 1:9-13.

Pope, M W M 1999 ${ }^{2}$ [1975]. The story of decipherment: From Egyptian hieroglyphics to Maya script. London: Thames \& Hudson.

Powell, J \& Gribble, F 1919. The history of Ruhleben: A record of British organization in a prison camp in Germany. London: W Collins \& Sons. 
Richardson, E 2013. Classical Victorians: Scholars, scoundrels and generals in pursuit of Antiquity. Classics after Antiquity. Cambridge: Cambridge University Press.

Ross, R 1999. A concise history of South Africa. Cambridge: Cambridge University Press.

Semeonoff, A E \& Tillyard, H J W 1917. Russian poetry reader. London: K Paul, Trench, Trubner \& Co.

Smail, W M 1938. Quintilian on education being a translation of selected passages from the Institutio oratoria with an introductory essay on Quintilian, his environment and his theory of education. Oxford: Clarendon Press.

Stray, C 2014. Review of Richardson, E 2013. Classical Victorians: Scholars, scoundrels and generals in pursuit of Antiquity. Classics after Antiquity. BMCR 2014.06.05: no pages.

Tillyard, H J W 1904-1905. Boundary and mortgage stones from Attica. The Annual of the British School at Athens 11:63-71.

1905-1906. Two watch towers in the Megarid. The Annual of the British School at Athens 12:101-108.

— 1908. Agathocles. Cambridge Historical Essays no. 15. Cambridge: Cambridge University Press.

- 1920. The modern Greek language question. South African Quarterly 2.vi: no pages.

1947. Keep up your Latin. $G \& R$ 16:67-71.

1952a. The stages of the early Byzantine musical notation. Byzantinische Zeitschrift 45:29-42.

1952b. Twenty canons from the Trinity Hirmologium. Monumenta musicae Byzantinae transcripta. Boston: The Byzantine Institute.

— 1953. The Byzantine modes in the twelfth century. The Annual of the British School at Athens 48:182-190.

1 1958. Prudentius in the classroom? G\&R 5.2:67-71.

— 1962. Suggestions for an adult beginner's Latin reader. $G \& R$ 9.1: 67-71.

— 1964. Verses for children and others. London.

Van Zyl, A J 1995. Die storie van Lantern, 1949-1995. Lantern 44.3:1-63.

Velimirović, M 1968. H J W Tillyard, patriarch of Byzantine studies. The Musical Quarterly 54.3:341-351.

Von Thiersch, F W $1829^{2}$. Über die Epochen der bildenden Kunst unter den Griechen. München.

Von Vacano, O W (trans. Ogilvie, S A) 1960 [1957]. The Etruscans in the ancient world. London: Edward Arnold.

Wellesz, E, Conomos, D E \& Velimirović, M M 1966. Studies in Eastern chant. Oxford University Press: London. 
Welsh, F 2000. A history of South Africa. London: Harper Collins.

Whitaker, G 2004. K D White. In Todd, R E (ed.) Dictionary of British Classicists. Bristol: Thoemmes Continuum.

Whitaker, R 1997. The Classics in South African society - Past, present and future. Acta Classica 40:5-14.

White, K D 1958. Our Classical tradition. Johannesburg: Publicity Dept., SABC.

1975. Farm equipment of the Roman world. Cambridge \& New York: Cambridge University Press.

— 1977. Country life in Classical times: An anthology of texts in translation. London: Elek.

- 1984. Greek and Roman technology. Aspects of Greek and Roman life. London: Thames \& Hudson. 